\title{
Effect of Grazing on the Plant Community of a Southern Brazilian Swamp
}

\author{
Jaqueline Spellmeier ${ }^{1}$, Eduardo Périco ${ }^{1}$ (D), Claus Haetinger ${ }^{1}$ (D), \\ Elisete Maria Freitas ${ }^{1}$, Ana Paula de Borba Morás ${ }^{1}$ \\ ${ }^{1}$ Universidade do Vale do Taquari - UNIVATES, Lajeado/RS, Brasi
}

\begin{abstract}
Swamps have high biological diversity and are the largest producers of biomass. However, such ecosystems are threatened by human activities. This study analyzes the plant community structure of two swamp sites, with and without grazing. A total of 200 sample units with $0.25 \mathrm{~m}^{2}$ were distributed every $13 \mathrm{~m}$ to determine diversity, the Importance Value Index (IVI), and coverage. Fifty species and 18 families were recorded. Luziola peruviana Juss. ex. JF Gmel had the highest IVI, accounting for $62.57 \%$ of the relative coverage in cattle-influenced sites. In the portions without cattle, Commelina diffusa Burm.f. had the highest IVI (24.33). The Shannon and Pielou indexes were 2.18 nats.ind. ${ }^{-1}$ and 0.56 , respectively, decreasing to 1.62 nats.ind. ${ }^{-1}$ and 0.47 in grazing sites. There was less richness in the cattle grazing area, with a single species accounting for a high percentage of coverage, indicating the possible role of grazing on the plant community structure.
\end{abstract}

Keywords: diversity indexes, phytosociology, wetlands. 


\section{INTRODUCTION}

Swamps, known in Brazil as brejos, pântanos, pantanal, charcos, varjões and alagados (bogs, swamps, sloughs, marshes, heaths, and quagmires), are areas associated with a soil constantly or temporarily flooded because of the water table (Kurtz et al., 2013). There are different opinions concerning the identification of these ecosystems. However, the following indicators allow for the classification of swamps: presence of shallow waters or saturated soil, plants and animals adapted to aquatic life, and accumulation of organic matter from decomposing plants (Carvalho \& Ozorio, 2007).

According to Sakané et al. (2011), Fonder \& Headley (2013) and Junk et al. (2014), wetlands can be classified considering hydrological and vegetation parameters, which are the most important attributes. Moreover, functional integrity and biodiversity values are observed. Among their attributes, a high biological diversity stands out, since they are considered the most productive environments in the world. In addition, organic matter production is eight times higher than in fields. This yield is the result of the links between water, soil, vegetation, and fauna. For this reason, they are strategic conservation sites (Carvalho \& Ozorio, 2007).

Among the components of biological diversity, aquatic macrophytes play an important role in nutrient cycling and storage, sheltering other aquatic organisms that act as bioindicators of trophic and successive stages in the ecosystem. They also contribute to water oxidation. However, it is only in the past few years that they have received scientific attention, since it was found that macroalgae have the possibility to remove water nutrients, inducing its application in wastewater treatment (Marinho-Soriano et al., 2011).

In Rio Grande do Sul, the southernmost state of Brazil, marshes occupy large areas in the southernmost portions of coastal plains (Kurtz et al., 2013). Notwithstanding, due to their vulnerability, these sites are threatened by urban growth, silting, drainage, and pollution (Carvalho \& Ozorio, 2007). Cattle grazing can be among the causes of these ecosystems degradation. This action, together with cattle trampling, can modify the physical environment and increase soil erosion (Rempel et al., 2018). Under high grazing intensity, there is a decrease in land coverage and changes occur in species replacement (Pandey \& Singh, 1991). This is especially critical for prostrate types, like stolons and rhizomes, or those whose biomass is concentrated closer to the ground. Conversely, without grazing there is a dominance of higher species and large clumping grasses (Boldrini \& Eggers, 1996), which are favored in the competition for light. Meanwhile, sustainable grazing can maintain species diversity and preserve ecosystems (Boldrini \& Eggers, 1996). Despite the importance of these ecosystems and their degree of degradation, phytosociological studies that provide better knowledge about the structure and dynamics of vegetal communities in swamps are not usual. The studies carried out recently in the coastal plains of Rio Grande do Sul (RS) by Rolon et al. (2008) and Kafer et al. (2011) stand out for their approach to the diversity and biomass of the vegetation in swamps. The lack of knowledge on biodiversity, especially about plant life, and the rate at which these ecosystems are being destroyed as a result of urban expansion, agricultural use, and cattle grazing highlight the need to broaden the information we have to preserve these ecosystems.

Based on the considerations mentioned above, this study assesses the plant community structure in a swamp, comparing sites affected by cattle (grazing) and others without the presence of cattle. It further contributes to a better understanding of the system and of the relationships between plant species.

\section{MATERIAL AND METHODS}

The swamp, with approximately 1,420 $\mathrm{m}$ in length and with widths varying between 50 and $106 \mathrm{~m}$, is located about $800 \mathrm{~m}$ from the Taquari River, between coordinates $29^{\circ} 33^{\prime} 17.68^{\prime \prime} \mathrm{S}$ and $29^{\circ} 34^{\prime} 7.92^{\prime \prime}$ S longitude and $51^{\circ} 58^{\prime} 21.54^{\prime \prime} \mathrm{W}$ and $51^{\circ} 58^{\prime} 23.99^{\prime \prime} \mathrm{W}$ latitude. The study site is in Arroio de Ouro, a rural district of Estrela City, RS (Figure 1). As a consequence of its proximity to the Taquari River, the swamp is constantly flooded in flood seasons. Furthermore, some portions are used for cattle grazing.

The region presents a temperate humid climate with hot summers (cfa) (Peel et al., 2007). The soil is classified as Orthic Haplic Chernosol (Streck et al., 2008), presenting reasonable levels of organic matter and high chemical fertility, a typical feature of the river floodplains that drain the lower northeast hillside. According to IBGE, the study area is located at the 


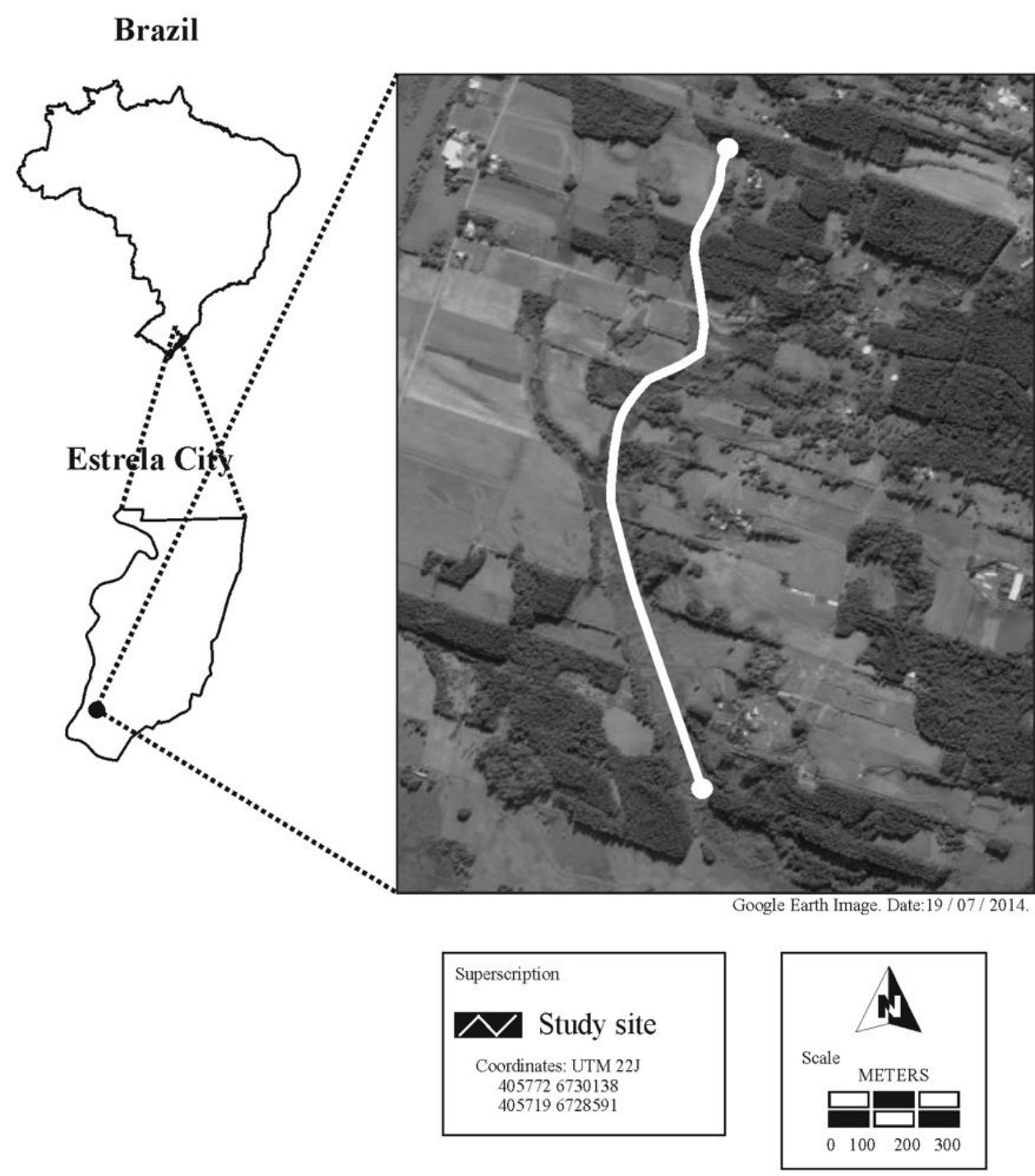

Figure 1. Swamp location in Estrela City, RS, and its position in relation to the Taquari River. Source: Image montage of Estrela City, 2006.

phytoecological formation of the Decidual Seasonal Forest, in the Atlantic Forest biome.

The study of the plant community was conducted in two portions of the swamp where there was cattle grazing (CP1 and CP2) and two fenced portions to which the cattle had no access (NC1 and NC2). It consisted of a phytosociological botanical survey following the plot method described by Matteucci \& Colma (1982). For botanical survey purposes, fertile botanical material was collected for identification with the aid of identification keys, expert advice, and herbaria. The material was herborized and added to the HVAT herbarium at the Natural Sciences Museum of UNIVATES. To define the botanical families, we followed APG IV (2016). Moreover, the scientific names of species were confirmed using the Brazilian Flora Checklist and the Missouri Botanical Garden nomenclature.

The forms of life identified in this study were amphibian species (AMP), earthy species (EAR), fixed emergent aquatic species (FIE), fixed floating aquatic species (FFA), free emergent aquatic species (FRE) and fixed submerged aquatic species (FSA). Sampling units (SUs) consisting of $0.25 \mathrm{~m}^{2}$ frames were systematically distributed every $13 \mathrm{~m}$, starting from the first sampling unit (SU), which was placed 
in a random spot. There were 100 SUs in the cattle grazing portions and 100 SUs in the portions without cattle. Given that the $\mathrm{CP} 1$ portion spans a larger area, 60 SUs were distributed, contrasting with the 40 SUs placed in the CP2 portion, which has a smaller area. The same happened in the portions without cattle grazing: 60 SUs were distributed in the $\mathrm{NC} 1$ area, and 40 SUs in the NC2 area.

In each SU, the percentage of occupied coverage area was visually determined by the horizontal projection of the shoots of each plant species, using a cover-abundance scale adapted from Braun-Blanquet (1979). The mean value of each class was adopted for calculation purposes. This allowed absolute and relative coverage and frequency parameters to be defined, as well as the Importance Value Index (IVI), for each species. The diversity for both swamp conditions was estimated using the Shannon (H'), Pielou equitability (J'), and Jaccard similarity (JS) indexes.

The IVIs of the two plant communities (with and without cattle) were tested using Spearman's correlation. The frequencies and relative coverages were compared using the Mann-Whitney test (Zar, 2010). Furthermore, the correlation between absolute frequency and absolute coverage of the portions, with and without cattle, was calculated. The curves obtained were corrected using the LAB Fit program (Silva et al., 2004).

\section{RESULTS AND DISCUSSION}

In the phytosociological survey performed using the total sampling from the swamp, 50 species were distributed into 33 genera and 18 families (Table 1).

Table 1. Species with their respective values of Absolute Coverage (AC), Relative Coverage (RC), Absolute Frequency (AF), Relative Frequency (RF), and Importance Value Index (IVI) in the area with and without cattle influence.

\begin{tabular}{|c|c|c|c|c|c|c|c|c|c|}
\hline \multirow[t]{3}{*}{ Species } & \multicolumn{3}{|c|}{ Total swamp area } & \multicolumn{3}{|c|}{$\begin{array}{c}\text { Land portions } \\
\text { without cattle } \\
\text { influence } \\
\end{array}$} & \multicolumn{3}{|c|}{$\begin{array}{l}\text { Land portions } \\
\text { with cattle } \\
\text { influence }\end{array}$} \\
\hline & RC & AF & IVI & RC & AF & IVI & RC & AF & IVI \\
\hline & $\%$ & $\%$ & $\%$ & $\%$ & $\%$ & IVI & $\%$ & $\%$ & IVI \\
\hline Commelina diffusa Burm.f. & 12.7 & 45.0 & 13.4 & 24.8 & 79.0 & 24.3 & 0.7 & 11.0 & 2.2 \\
\hline Luziola peruviana Juss. ex J.F.Gmel. & 45.2 & 73.5 & 34.2 & 27.7 & 47.0 & 20.9 & 62.6 & 100.0 & 47.7 \\
\hline Hymenachne grumosa (Nees) Zuloaga & 9.1 & 18.5 & 7.5 & 16.7 & 30.0 & 12.9 & 1.5 & 7.0 & 1.9 \\
\hline Hygrophila costata Nees & 2.2 & 8.5 & 2.4 & 4.4 & 17.0 & 4.8 & 0.0 & 0.0 & 0.0 \\
\hline Rhynchospora asperula (Nees) Steud. & 3.0 & 9.5 & 3.0 & 4.4 & 14.0 & 4.3 & 1.7 & 5.0 & 1.7 \\
\hline Polygonum punctatum Elliott & 3.4 & 23.0 & 5.3 & 2.1 & 19.0 & 3.9 & 4.6 & 27.0 & 6.7 \\
\hline Paspalum sp. 2 & 1.0 & 7.5 & 1.7 & 1.8 & 14.0 & 3.0 & 0.3 & 1.0 & 0.3 \\
\hline Myriophyllum aquaticum (Vell.) Verdc. & 0.3 & 9.0 & 1.6 & 0.4 & 15.0 & 2.5 & 0.2 & 3.0 & 0.6 \\
\hline Alternanthera philoxeroides (Mart.) Griseb. & 1.3 & 16.5 & 3.2 & 0.8 & 13.0 & 2.4 & 1.8 & 20.0 & 4.2 \\
\hline Polygonum glabrum Willd. & 1.0 & 8.0 & 1.8 & 1.3 & 11.0 & 2.3 & 0.7 & 5.0 & 1.2 \\
\hline Ludwigia hexapetala (Hook. \& Arn.) Zardini et al. & 1.7 & 7.5 & 2.0 & 1.8 & 6.0 & 1.8 & 1.5 & 9.0 & 2.2 \\
\hline Ludwigia multinervia (Hook. \& Arn.) Ramamoorthy & 0.7 & 3.5 & 0.9 & 1.4 & 7.0 & 1.7 & 0.0 & 0.0 & 0.0 \\
\hline Eleocharis obtusetrigona (Lindl. \& Nees) Steud. & 0.6 & 6.5 & 1.3 & 0.9 & 8.0 & 1.7 & 0.2 & 5.0 & 1.0 \\
\hline Hymenachne amplexicaulis (Rudge) Nees & 1.0 & 2.0 & 0.8 & 2.0 & 4.0 & 1.6 & 0.0 & 0.0 & 0.0 \\
\hline Hymenachne donacifolia (Raddi) Chase & 0.7 & 2.5 & 0.7 & 1.0 & 4.0 & 1.1 & 0.3 & 1.0 & 0.3 \\
\hline Polygonum ferrugineum Wedd. & 0.3 & 2.5 & 0.6 & 0.6 & 5.0 & 1.1 & 0.0 & 0.0 & 0.0 \\
\hline Paspalum sp. 1 & 1.2 & 2.0 & 0.9 & 1.4 & 2.0 & 1.0 & 1.0 & 2.0 & 0.8 \\
\hline Paspalum acuminatum Raddi & 0.3 & 4.0 & 0.8 & 0.4 & 5.0 & 1.0 & 0.1 & 3.0 & 0.6 \\
\hline Mikania micrantha Kunth & 0.3 & 2.0 & 0.5 & 0.6 & 4.0 & 0.9 & 0.0 & 0.0 & 0.0 \\
\hline Enydra anagallis Gardner & 5.6 & 22.5 & 6.3 & 0.3 & 4.0 & 0.7 & 10.9 & 41.0 & 12.2 \\
\hline Vernonanthura tweediana (Baker) H.Rob. & 0.3 & 1.0 & 0.3 & 0.7 & 2.0 & 0.6 & 0.0 & 0.0 & 0.0 \\
\hline Ipomoea grandifolia (Dammer) O'Donell & 0.3 & 1.0 & 0.3 & 0.7 & 2.0 & 0.6 & 0.0 & 0.0 & 0.0 \\
\hline Eleocharis montana (Kunth) Roem. \& Schult. & 0.4 & 2.5 & 0.6 & 0.6 & 2.0 & 0.6 & 0.3 & 3.0 & 0.6 \\
\hline Paspalum vaginatum $\mathrm{Sw}$. & 0.3 & 0.5 & 0.3 & 0.7 & 1.0 & 0.5 & 0.0 & 0.0 & 0.0 \\
\hline Ipomoea alba L. & 0.2 & 1.0 & 0.3 & 0.4 & 2.0 & 0.5 & 0.0 & 0.0 & 0.0 \\
\hline
\end{tabular}


Table 1. Continued...

\begin{tabular}{|c|c|c|c|c|c|c|c|c|c|}
\hline \multirow[t]{3}{*}{ Species } & \multicolumn{3}{|c|}{ Total swamp area } & \multicolumn{3}{|c|}{$\begin{array}{c}\text { Land portions } \\
\text { without cattle } \\
\text { influence }\end{array}$} & \multicolumn{3}{|c|}{$\begin{array}{c}\text { Land portions } \\
\text { with cattle } \\
\text { influence }\end{array}$} \\
\hline & $\mathbf{R C}$ & AF & IVI & $\mathbf{R C}$ & AF & IVI & $\mathbf{R C}$ & AF & IVI \\
\hline & $\%$ & $\%$ & $\%$ & $\%$ & $\%$ & IV 1 & $\%$ & $\%$ & IVI \\
\hline Carex polysticha Boeckeler & 0.3 & 0.5 & 0.2 & 0.5 & 1.0 & 0.4 & 0.0 & 0.0 & 0.0 \\
\hline Ipomoea cairica (L.) Sweet & 0.1 & 1.0 & 0.2 & 0.2 & 2.0 & 0.4 & 0.0 & 0.0 & 0.0 \\
\hline Sagittaria montevidensis Cham. \& Schltdl. & 0.3 & 4.5 & 0.9 & 0.3 & 1.0 & 0.3 & 0.3 & 8.0 & 1.5 \\
\hline Eryngium pandanifolium Cham. \& Schltdl. & 0.2 & 0.5 & 0.2 & 0.3 & 1.0 & 0.3 & 0.0 & 0.0 & 0.0 \\
\hline Neocabreria serrulata (DC.) R.M.King \& H.Rob. & 0.2 & 0.5 & 0.2 & 0.3 & 1.0 & 0.3 & 0.0 & 0.0 & 0.0 \\
\hline Cyperus virens Michx. & 0.1 & 1.0 & 0.2 & 0.2 & 1.0 & 0.2 & 0.1 & 1.0 & 0.2 \\
\hline Juncus densiflorus Kunth & 0.1 & 0.5 & 0.1 & 0.2 & 1.0 & 0.2 & 0.0 & 0.0 & 0.0 \\
\hline Juncus microcephalus Kunth & 0.1 & 0.5 & 0.1 & 0.2 & 1.0 & 0.2 & 0.0 & 0.0 & 0.0 \\
\hline Salix humboldtiana Willd. & 0.1 & 0.5 & 0.1 & 0.2 & 1.0 & 0.2 & 0.0 & 0.0 & 0.0 \\
\hline Senecio juergensii Mattf. & 0.0 & 0.5 & 0.1 & 0.1 & 1.0 & 0.2 & 0.0 & 0.0 & 0.0 \\
\hline Paspalum conjugatum P.J. Bergius & 0.7 & 3.0 & 0.8 & 0.1 & 1.0 & 0.2 & 1.4 & 5.0 & 1.5 \\
\hline Centella asiatica (L.) Urb & 0.1 & 1.0 & 0.2 & 0.0 & 1.0 & 0.2 & 0.1 & 1.0 & 0.2 \\
\hline Ludwigia peruviana (L.) H. Hara & 0.0 & 0.5 & 0.1 & 0.0 & 1.0 & 0.2 & 0.0 & 0.0 & 0.0 \\
\hline Hydrocotyle ranunculoides L.f. & 1.6 & 10.0 & 2.4 & 0.0 & 0.0 & 0.0 & 3.1 & 20.0 & 4.8 \\
\hline Hymenachne pernambucensis (Spreng.) Zuloaga & 1.5 & 3.0 & 1.2 & 0.0 & 0.0 & 0.0 & 2.9 & 6.0 & 2.5 \\
\hline Cyperus blepharoleptos Steud. & 1.0 & 3.5 & 1.1 & 0.0 & 0.0 & 0.0 & 2.0 & 7.0 & 2.2 \\
\hline Eichhornia azurea (Sw.) Kunth & 0.3 & 2.0 & 0.5 & 0.0 & 0.0 & 0.0 & 0.7 & 4.0 & 1.0 \\
\hline Eichhornia crassipes (Mart.) Solms & 0.2 & 1.0 & 0.3 & 0.0 & 0.0 & 0.0 & 0.5 & 2.0 & 0.6 \\
\hline Salvinia herzogii de la Sota & 0.1 & 1.0 & 0.2 & 0.0 & 0.0 & 0.0 & 0.2 & 2.0 & 0.4 \\
\hline Cuphea glutinosa Cham. \& Schltdl. & 0.1 & 0.5 & 0.1 & 0.0 & 0.0 & 0.0 & 0.2 & 1.0 & 0.2 \\
\hline Setaria parviflora (Poir.) Kerguélen & 0.1 & 0.5 & 0.1 & 0.0 & 0.0 & 0.0 & 0.2 & 1.0 & 0.2 \\
\hline Justicia comata (L.) Lam. & 0.0 & 0.5 & 0.1 & 0.0 & 0.0 & 0.0 & 0.1 & 1.0 & 0.2 \\
\hline Cyperus brevifolius (Rottb.) Endl. ex Hassk. & 0.0 & 0.5 & 0.1 & 0.0 & 0.0 & 0.0 & 0.0 & 1.0 & 0.2 \\
\hline Juncus tenuis Willd. & 0.0 & 0.5 & 0.1 & 0.0 & 0.0 & 0.0 & 0.0 & 1.0 & 0.2 \\
\hline Heteranthera reniformis Ruiz \& Pav. & 0.0 & 0.5 & 0.1 & 0.0 & 0.0 & 0.0 & 0.0 & 1.0 & 0.2 \\
\hline
\end{tabular}

In the portions without cattle (NC1 and NC2), 38 species and 14 families were recorded; and 32 species and 16 families were recorded in the presence of cattle (CP1 and CP2). Considering the entire swamp, the families with the highest abundance were Poaceae, with 11 species; Cyperaceae, with seven species; and Asteraceae, with five species. These families are also among the main families recorded in papers related to grassland vegetation (Freitas et al., 2009; Pinto et al., 2013; Menezes et al., 2013). Asteraceae presented a higher abundance in the portions without cattle influence, while Poaceae and Cyperaceae showed almost the same number of species in both areas. Poaceae and Cyperaceae families totaled $36 \%$ of the sampled species. These two families totaled $74.62 \%$ and $58.18 \%$ of the relative coverage in the areas with and without cattle, respectively.

Similar results were obtained in other swamps in Rio Grande do Sul State. Rolon et al. (2008) evaluated species richness and environmental variables in a coastal plain in RS, near the National Park of Lagoa do Peixe. They recorded a total of 105 species from 15 wetlands in a year, with a high percentage (100\%) in the frequency of species from the families Cyperaceae, Poaceae and Menyanthaceae. Moreover, Spellmeier et al. (2009) recorded the occurrence of 145 species and 44 families in a swamp in Estrela City, RS. In that study, Asteraceae, Poaceae, and Cyperaceae were the most important families regarding the number of species. Kafer et al. (2011) conducted a botanical survey in a continental swamp in Rio Grande, listing 82 species and 33 families, among which the most important in terms of number of species were also Cyperaceae, Asteraceae, and Poaceae. In turn, Rolon et al. (2011) conducted a survey of aquatic macrophytes in humid areas of the Parque Nacional da Lagoa do Peixe, RS, sampling 176 species and 44 families, with Cyperaceae, 
Poaceae, Juncaceae, and Asteraceae being the most important.

In addition to those families with an elevated number of species, we recorded species of Pontederiaceae, Juncaceae, and Salviniaceae, which are typical families in swamps (Pott et al., 2011; Kozera et al., 2009; Kufner et al., 2011; Rolon et al., 2010).

As mentioned before, in the two swamp portions without cattle, 38 species were recorded. In the two portions with cattle, 32 species were recorded. This greater richness observed in the area without cattle contradicts Sala et al. (1986), Taddese et al. (2002), Jones et al. (2010), and Mohandass et al. (2016), who claim that grazing areas, in general, show a larger number of species than non-grazing areas. Following the same concept, Kilca et al. (2011) analyzed the floristic diversity in Pampa biome phytophysiognomies, including swamps. The authors found a huge diversity of flora species, even with signs of drainage in riparian zones for cattle grazing. Nonetheless, Sala et al. (1986), Deng et al. (2013), and Mohandass et al. (2016) state that different intensities of grazing can alter the diversity and structure of the community. According to the same authors, higher and lower intensities cause a reduction in the number of species because low stocking promotes the presence of cespitose species in detriment to prostrate ones that, without grazing, tend to disappear. This is what happened in the area under study, since there was a smaller number of species and dominance of cespitose species in the area with and without cattle, respectively, indicating high grazing intensity.

Regarding the forms of life (Figure 2), AMP were prevalent (48.9\% of the total samples from the portions without cattle and $36.8 \%$ from those with cattle), followed by FIE, EAR, FFA, and FRE. There were no significant differences between the portions with and without cattle for all forms of life.

The botanical similarity between the two swamp use conditions was 0.39 according to the Jaccard index, which means that nearly $40 \%$ of the species are common to both areas. Of the 50 species sampled in the phytosociological survey, 20 were common to both environments, 12 were exclusive to the areas with cattle, and 18 were exclusive to the areas without cattle. Therefore, grazing promotes some species in the same way that the absence of grazing promotes others, yet some species tolerate grazing and also survive in its absence. When not under the influence of cattle, the height of the vegetation varied from 50 to $150 \mathrm{~cm}$, while in the grazing areas it varied from $10 \mathrm{~cm}$ to $50 \mathrm{~cm}$. The highest height was recorded in some clumps containing species of Poaceae, showing a clear difference between the two swamp use conditions. It is likely that grazing was responsible for this difference, as it promotes vegetal biomass, mainly in dry periods, when cattle advances over more humid areas, where vegetation stays greener.

The species which showed the highest IVIs, considering the entire swamp, were Luziola peruviana (34.16), Commelina diffusa (13.43), Hymenachne grumosa (7.45), Enydra anagallis (6.34), Polygonum punctatum (5.29), Alternanthera philoxeroides (3.23), Rhynchospora asperula (3.01), Hydrocotyle ranunculoides (2.36), Ludwigia hexapetala (2.00), and Polygonum glabrum (1.77). Considering only the portions without the influence of cattle, the order of the first two species shifts. $C$. diffusa ranks first $(\mathrm{IVI}=24.33)$ with a relative

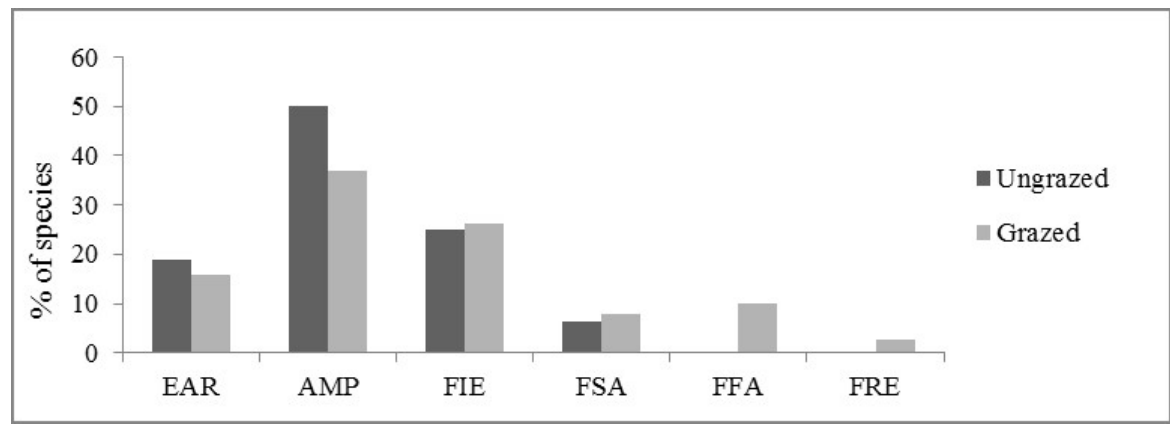

Figure 2. Percentages of forms of life with and without grazing. EAR - earthy species; AMP - amphibian species; FIE - fixed emergent aquatic species; FSA - fixed submerged aquatic species; FFA - fixed floating aquatic species; FRE - free emergent aquatic species. 
cover (RC) and absolute frequency (AF), followed by L. peruviana (IVI $=20.93$ ). On the other hand, in the portions with grazing, L. peruviana holds the first position with an IVI of 47.68 , much higher compared to Enydra anagallis, the species in the second position $(I V I=12.16)$. This marked difference between the first two species occurred because the first was present in all the SUs and accounted for a higher RC percentage, while $E$. anagallis showed a smaller $\mathrm{AF}$ and a low RC percentage. One single species accounted for more than $50 \%$ of the total coverage of the area, demonstrating that with the presence of cattle, few species were responsible for a larger percentage of cover. Furthermore, there was a reduction in diversity, shown by the low diversity index $\left(\mathrm{H}^{\prime}=1.62\right.$ nats.ind. $\left.^{-1}\right)$ and Pielou equitability index $(J=0.47)$. In the non-grazing areas, these indexes were 2.24 and 0.6, respectively, amounts that were a little higher than the ones obtained from the grazing areas.

The phytosociological survey clearly showed that grazing promotes changes in the plant community. L. peruviana, with a higher RC percentage in grazing sites, has its coverage reduced considerably in portions without grazing. C. diffusa ranked first in relation to IVI when there was no grazing, moving to the eighth position in grazing sites, which may be related to its palatability to cattle, or even to an intolerance to grazing. On the other hand E. anagallis, second position in the presence of cattle, was in the twentieth position $(I V I=0.74)$ in the portions without the presence of cattle. However, Hydrocotyle ranunculoides, Hymenachne pernambucensis, and Cyperus blepharoleptos were among the species with the highest IVIs in grazing areas, but they were not recorded in areas without grazing. Where there was no grazing, Rhynchospora asperula, Paspalum sp.2, Myriophyllum aquaticum, and Polygonum glabrum were among the species with the highest IVIs, but moved to much lower positions when influenced by cattle.

An IVI comparison between the two vegetations existing in the portions with and without cattle showed significant differences between the values gathered $\left(r_{s}=0.5011 ; p=0.0243\right)$. This indicates that some species were favored by the exclusion of grazing, while others were favored by its presence. The Mann-Whitney test $(\mathrm{U}=1231.0 ; \mathrm{p}=0.6418)$ demonstrated that there was no significant difference in Relative Frequency (RF) between the portions with and without the influence of cattle.

There was a correlation between absolute frequency (y) and absolute coverage $(x)$ (Figure 3), which in the area without cattle presented a potential trend towards a natural logarithm, $\mathrm{y}=\frac{0.45 * \mathrm{x}^{0.86}}{\ln (\mathrm{x})}\left(\mathrm{r}^{2}=0.84\right)$. The same relationship in the area with cattle (Figure 4)

Correlation between Absolute Frequency and Absolute Coverage in the area without cattle.

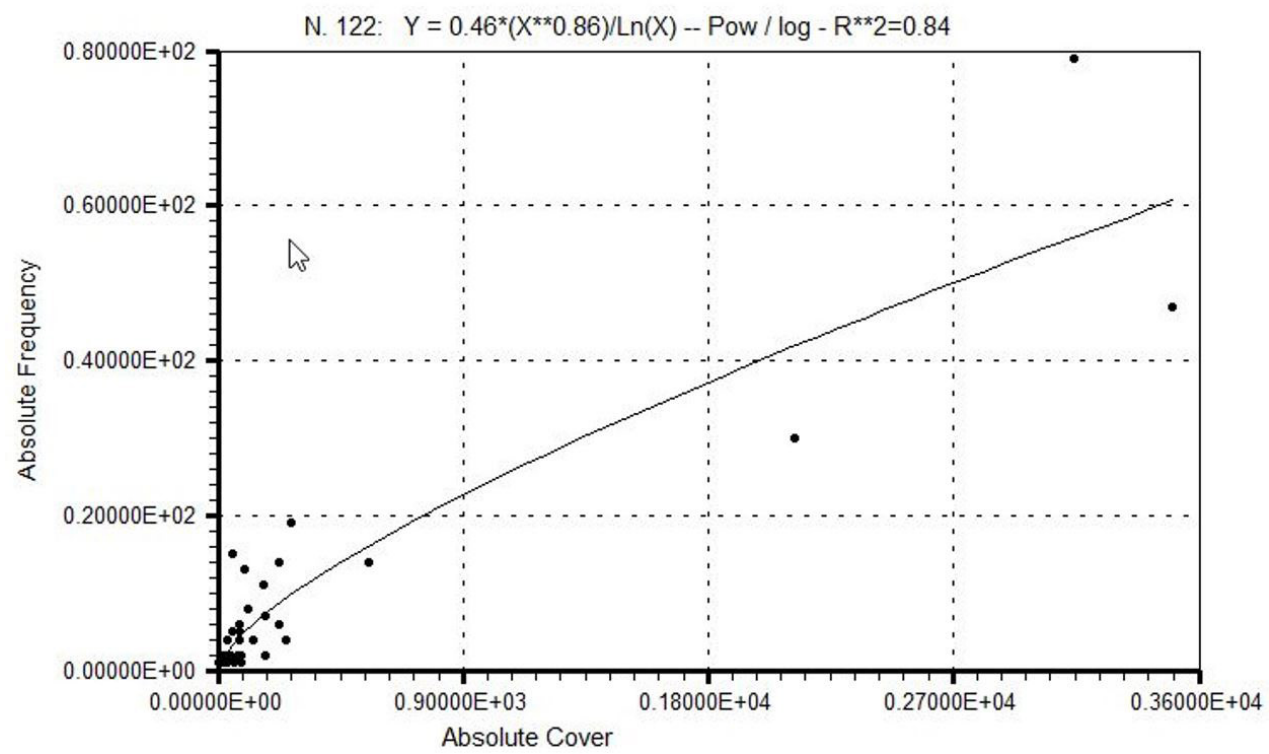

Figure 3. Correlation between Absolute Frequency and Absolute Coverage in the area without cattle. 
Correlation between Absolute Frequency and Absolute Cover in the area with cattle

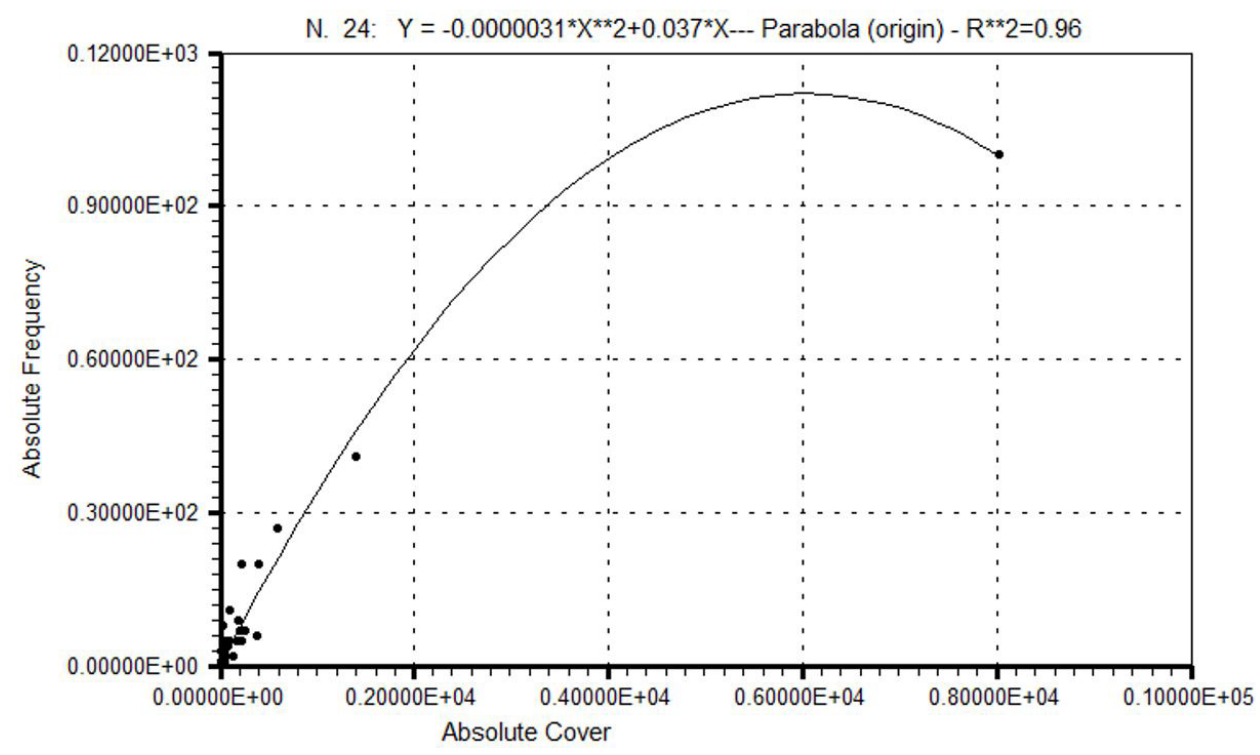

Figure 4. Correlation between Absolute Frequency and Absolute Coverage in the area with cattle.

demonstrated a polynomial trend, $y=-0.0000031 * x^{2}$ $+0.037^{\star} x$ (parabola passing through the origin), due to the high absolute coverage presented by Luziola peruviana $\left(r^{2}=0.96\right)$.

The Shannon $(\mathrm{H})$ indexes for the vegetation in portions with and without cattle were $\mathrm{H}=1.62$ nats. ind. ${ }^{-1}$ and $\mathrm{H}=2.29$ nats.ind. ${ }^{-1}$, respectively, showing a significant difference $(t=5.612 ; \mathrm{df}=600 ; \mathrm{p}<0.001)$ and indicating that the area without cattle showed a higher abundance, contradicting the predation hypothesis resulting from herbivorous tendencies (Marion et al., 2010). According to this hypothesis, there is an increase in abundance when predators prevent dominant species from monopolizing resources. According to Sun et al. (2011) and Reid et al. (2011), grazing is a disturbance because it acts as a limiting mechanism for plant biomass. Moreover, it significantly influences vegetation growth and its composition, which modifies the abundance of forms of life such as plants and insects (Dumont et al., 2009). Therefore, disturbance and disorders are considered to be the main factors controlling the community structure. According to Spellmeier et al. (2009), the connection between the portions with and without cattle in the swamp studied may be a determinant factor for the elevated number of species found, although a low number was recorded for $H^{\prime}$ (2.18 nats.ind. $\left.{ }^{-1}\right)$ and Pielou equitability (0.56) when compared to other studies. Boldrini et al. (2008) present a Shannon-Wiener Index of 2.977 nats.ind. ${ }^{-1}$, and Pielou of 0.68 in a phytosociological study carried out on the shores of the Armazém lagoon in Osório, RS. Ferreira \& Setubal (2009) conducted floristic and phytosociological studies in a natural grassland in Santo Antônio da Patrulha, RS, Brazil, and found high $H^{\prime}$ and J' values, 3.63 nats.ind. ${ }^{-1}$ and 0.87 , respectively. Lehn et al. (2011), who used two quantitative methods in a phytosociological survey of aquatic macrophytes associated with Rio Miranda, in Pantanal, MS, Brazil, obtained Shannon-Wiener index ( $\left.\mathrm{H}^{\prime}\right)$ of 2.44 and 2.47 nats.ind. ${ }^{-1}$.

\section{CONCLUSIONS}

The smaller abundance and diversity in the area with cattle suggests a consistent association between the cattle grazing effect and the abundance of species. This is proven in the two portions under the influence of cattle, where the community structure was negatively influenced, with a reduction in the outcomes of these variables. Grazing tends to favor only certain species. Therefore, it is important that areas affected by cattle grazing are managed properly so that plant communities are not affected. 


\section{ACKNOWLEDGEMENTS}

The authors thank the support of the Postgraduate Program in Environment and Development of Univates.

\section{SUBMISSION STATUS}

Received: 30 aug., 2018

Accepted: 27 nov., 2018

\section{CORRESPONDENCE TO}

\section{Claus Haetinger}

Centro de Ciências Exatas e Tecnológicas, Universidade do Vale do Taquari - UNIVATES, Avenida Avelino Tallini, 171, CEP 95914-014, Lajeado, RS, Brasil

e-mail: chaet@univates.br

\section{REFERENCES}

Angiosperm Phylogeny Group - APG. An update of the Angiosperm Phylogeny Group classification for the orders and families of flowering plants: APG IV. Botanical Journal of the Linnean Society 2016; 181(1): 1-20. <http:// dx.doi.org/10.1111/boj.12385>

Boldrini II, Eggers L. Vegetação campestre do sul do Brasil: resposta e dinâmica de espécies à exclusão. Acta Botanica Brasílica 1996; 10(1): 37-50. <http://dx.doi.org/10.1590/ S0102-33061996000100004>

Boldrini II, Trevisan R, Schneider AA. Estudo florístico e fitossociológico de uma área às margens da lagoa do Armazém, Osório, Rio Grande do Sul, Brasil. Revista Brasileira de Biociências 2008; 6: 355-367.

Braun-Blanquet J. Fitosociología: bases para el estudio de las comunidades vegetales. Madrid: H. Blume Ediciones Rosario; 1979.

Carvalho ABP, Ozorio CP. Avaliação sobre os banhados do Rio Grande do Sul, Brasil. Revista de Ciências Ambientais 2007; 1: 83-95.

Deng L, Sweeney S, Shangguan ZP. Grassland responses to grazing disturbance: plant diversity changes with grazing intensity in a desert steppe. Grass and Forage Science 2013; 69(3): 524-533. <http://dx.doi.org/10.1111/gfs.12065>

Dumont B, Farruggia A, Garel JP, Bachelard P, Boitier E, Frain M. How does grazing intensity influence the diversity of plants and insects in a species-rich upland grassland on basalt soils? Grass and Forage Science 2009; 64(1): 92-105. <http://dx.doi.org/10.1111/j.1365-2494.2008.00674.x>

Ferreira PMA, Setubal RB. Florística e fitossociologia de um campo natural no município de Santo Antônio da
Patrulha, Rio Grande do Sul, Brasil. Revista Brasileira de Biociências 2009; 7(2): 195-204.

Fonder N, Headley T. The taxonomy of treatment wetlands: A proposed classification and nomenclature system. Ecological Engineering 2013; 51: 203-211. <http://dx.doi. org/10.1016/j.ecoleng.2012.12.011>

Freitas EM, Boldrini II, Müller SC, Verdum R. Florística e fitossociologia da vegetação de um campo sujeito à arenização no sudoeste do Estado do Rio Grande do Sul, Brasil. Acta Botanica Brasílica 2009; 23(2): 414-426. <http://dx.doi.org/10.1590/S0102-33062009000200013>

Jones WM, Fraser LH, Curtis PJ. Plant community functional shifts in response to livestock grazing in intermountain depressional wetlands in British Columbia, Canada. Biological Conservation 2010; 144(1): 511-517. <http:// dx.doi.org/10.1016/j.biocon.2010.10.005>

Junk WJ, Piedade MTF, Lourival R, Wittmann F, Kandus P, Lacerda LD et al. Brazilian wetlands: their definition, delineation, and classification for research, sustainable management, and protection. Aquatic Conservation 2014; 24(1): 5-22. <http://dx.doi.org/10.1002/aqc.2386>

Kafer DS, Colares IG, Hefler SM. Composição florística e fitossociologia de macrófitas aquáticas em um banhado continental em Rio Grande, RS, Brasil. Rodriguésia 2011; 62(4): 835-846. <http://dx.doi.org/10.1590/S217578602011000400011>

Kilca RV, Jarenkow JA, Soares JCW, Garcia EN. Florística e fitofisionomias da planície de inundação do rio Piratini e sua importância para conservação no Pampa do Rio Grande do Sul, Brasil. Neotropical Biology and Conservation 2011; 6(3): 227-249.

Kozera C, Kuniyoshi YS, Galvão F, Curcio GR. Composição florística de uma formação pioneira com influência fluvial em Balsa Nova, PR, Brasil. Floresta 2009; 39(2): 309-322. <http://dx.doi.org/10.5380/rf.v39i2.14558>

Kufner DCL, Scremin-Dias E, Guglieri-Caporal A. Composição florística em variação sazonal da biomassa de macrófitas aquáticas em lagoa de meandro do Pantanal. Rodriguésia 2011; 62(4): 803-812. <http://dx.doi.org/10.1590/ S2175-78602011000400008>

Kurtz BC, Gomes JC, Scarano FR. Structure and phytogeographic relationships of swamp forests of Southeast Brazil. Acta Botanica Brasílica 2013; 27(4): 647-660. <http://dx.doi.org/10.1590/S0102-33062013000400002>

Lehn CR, Bueno ML, Kufner DCL, Scremin-Dias E, Pott VJ, Junior GAD. Fitossociologia de Macrófitas Aquáticas associadas ao Rio Miranda, Pantanal, MS, Brasil. Revista de Biologia Neotropical 2011; 8(2): 23-31.

Marinho-Soriano E, Azevedo CAA, Trigueiro TG, Pereira DC, Carneiro MAA, Camara MR. Bioremediation of aquaculture wastewater using macroalgae and Artemia. International Biodeterioration \& Biodegradation 2011; 65(1): 253-257. <http://dx.doi.org/10.1016/j.ibiod.2010.10.001> 
Marion B, Bonis A, Bouzillé J. How much does grazinginduced heterogeneity impact plant diversity in wet grasslands? Ecoscience 2010; 17(3): 229-239. <http:// dx.doi.org/10.2980/17-3-3315>

Matteucci SD, Colma A. Metodologia para el estudio de la vegetation. Washington: Secretaria General de la Organización de los Estados Americanos; 1982.

Menezes LS, Leite SLC, Ritter MR. Florística de um fragmento de restinga em Imbé, Rio Grande do Sul, Brasil. Pesquisas. Botânica 2013; 64: 141-155.

Mohandass D, Campbell MJ, Beng KC, Davidar P. Influence of grazing intensity on swamp plant communities in the tropical montane wetland ecosystems, Nilgiris, Southern India. Applied Ecology and Environmental Research 2016; 14(4): 233-268. <http://dx.doi.org/10.15666/ aeer/1404_233268>

Pandey CB, Singh JS. Influence of grazing and soil conditions on secondary savanna vegetation in India. Journal of Vegetation Science 1991; 2(1): 95-102. <http:// dx.doi.org/10.2307/3235901>

Peel MC, Finlayson BL, Mcmahon TA. Updated world map of the Köppen-Geiger climate classification. Hydrology and Earth System Sciences. European Geosciences Union 2007; 11: 1633-1644.

Pinto MF, Nabinger C, Boldrini II, Ferreira PMA, Setubal $\mathrm{RB}$, Trevisan $\mathrm{R}$ et al. Floristic and vegetation structure of a grassland plant community on shallow basalt in southern Brazil. Acta Botanica Brasílica 2013; 27(1): 162-179. <http://dx.doi.org/10.1590/S0102-33062013000100017>

Pott VJ, Pott A, Lima LCP, Moreira SN, Oliveira AKM. Aquatic macrophyte diversity of the Pantanal wetland and upper basin. Brazilian Journal of Biology = Revista Brasileira de Biologia 2011;71(1, Suppl 1): 255-263. <http://dx.doi.org/10.1590/S1519-69842011000200004> $<$ PMid:21537598>

Reid MA, Ogden R, Thoms MC. The influence of flood frequency, geomorphic setting and grazing on plant communities and plant biomass on a large dryland floodplain. Journal of Arid Environments 2011; 75(9): 815826. <http://dx.doi.org/10.1016/j.jaridenv.2011.03.014>

Rempel C, Morás APB, Bica JB, Herrmann MF. Flora arbórea e arborescente de Áreas de Preservação Permanente em propriedades rurais produtoras de leite no Vale do Taquari, Rio Grande do Sul, Brasil. Pesquisas. Botânica 2018; 71: 29-45.
Rolon AS, Homem HF, Maltchik L. Aquatic macrophytes in natural and managed wetlands of Rio Grande do Sul State, Southern Brazil. Acta Limnologica Brasiliensia 2010; 22(2): 133-146. <http://dx.doi.org/10.1590/S2179975X2010000200003>

Rolon AS, Lacerda T, Maltchik L, Guadagnin DL. Influence of area, habitat and water chemistry on richness and composition of macrophyte assemblages in southern Brazil wetlands. Journal of Vegetation Science 2008; 19(2): 221-228. <http://dx.doi.org/10.3170/2008-8-18359>

Rolon AS, Rocha O, Maltchik L. Diversidade de macrófitas aquáticas do Parque Nacional da Lagoa do Peixe. Neotropical Biology and Conservation 2011; 6(1): 5-12. <http://dx.doi. org/10.4013/nbc.2011.61.02>

Sakané N, Alvarez M, Becker M, Böhme B, Handa C, Kamiri HW et al. Classification, characterisation, and use of small wetlands in East Africa. Wetlands 2011; 31(6): 1103-1116. <http://dx.doi.org/10.1007/s13157-011-0221-4>

Sala OE, Oesterheld M, León RJC, Soriano A. Grazing effects upon plant community struture in subhumid grasslands of Argentina. Vegetatio 1986; 67: 27-32.

Silva WP, Silva CMDPS, Cavalcanti CGB, Silva DDPS, Soares IB, Oliveira JAS et al. LAB Fit ajuste de curvas: um software em português para tratamento de dados experimentais. Revista Brasileira de Ensino de Física 2004; 26(4): 419-427. <http://dx.doi.org/10.1590/S1806$11172004000400018>$

Spellmeier J, Périco E, Freitas EM. Composição florística de um banhado no município de Estrela/Rio Grande do Sul. Pesquisas. Botânica 2009; 60: 367-381.

Streck EV, Kämpf N, Dalmolin RSD, Klamt E, Nascimento PC, Schneider P et al. Solos do Rio Grande do Sul. Porto Alegre: EMATER; RS-ASCAR; 2008

Sun DS, Wesche K, Chen DD, Zhang SH, Wu GL, Du GZ et al. Grazing depresses soil carbon storage through changing plant biomass and composition in a Tibetan alpine meadow. Plant, Soil and Environment 2011; 57(6): 271-278. <http://dx.doi.org/10.17221/7/2011-PSE>

Taddese G, Saleem MA, Astatke A, Ayaleneh W. Effect of grazing on plant attributes and hydrological propertiers in the sloping lands of the east African highlands. Environmental Management 2002; 30(3): 406-417. <http:// dx.doi.org/10.1007/s00267-002-2727-2> <PMid:12148074>

Zar JH. Biostatistical analysis. 5th ed. London: PrenticeHall; 2010. 